\title{
The eco-city and its core environmental dimension of sustainability: green energy technologies and their integration with data-driven smart solutions
}

Simon Elias Bibri ${ }^{1,2}$

\footnotetext{
Correspondence: simoe@ntnu.no ${ }^{1}$ Department of Computer Science, The Norwegian University of Science and Technology, Sem Saelands veie 9, NO-7491, Trondheim, Norway

${ }^{2}$ Department of Architecture and Planning, The Norwegian University of Science and Technology, Alfred Getz vei 3, Sentralbygg 1, 5th floor, NO-7491, Trondheim, Norway
}

\begin{abstract}
Ecological urbanism is seen today as one of the keys towards unlocking the quest for a low-carbon or fossil fuel-free society. Global and local policies promote and advocate the eco-city as the most environmentally sound model of sustainable urbanism. It is argued that the eco-city strategies and solutions are expected to deliver positive outcomes in terms of minimal demand on energy resources and thus minimal environmental impacts. Moreover, it has recently been suggested that the eco-city needs to embrace and leverage what advanced ICT has to offer, particularly with regard to sustainable energy systems, so as to improve and advance its contribution to the goals of environmental sustainability. This paper examines how the eco-city especially its core environmental dimension is practiced and justified in urban planning and development with respect to sustainable energy systems and their integration with data-driven smart technologies at the district level. To illuminate this urban phenomenon accordingly, a descriptive case study is adopted as a qualitative research methodology where the empirical basis is formed by urban planning and development documents combined with secondary data and scientific literature. To provide a theoretical foundation and produce a rationale for this study, this paper first provides a state-of-the-art review of the field of ecological urbanism in terms of its foundations, models, strategies, research issues, as well as data-driven smart technological trends. This study shows that the Eco-city District of Stockholm Royal Seaport uses green energy and data-driven smart technologies as the key strategies and solutions for achieving the environmental objectives of sustainable development in terms of lowering energy consumption and mitigating pollution. This entails conserving and decreasing the demand for energy through renewable resources (i.e., sun, wind, and water), bio-fuelled Combined Heat Power system, large-scale smart grid system, energy management, sustainable waste management, and passive solar houses. This research enhances the scholarly community's current understanding of the emerging phenomenon of the smart ecocity with respect to the synergic potential of the integration of its sustainable energy strategies with data-driven technology solutions for advancing environmental sustainability.

(Continued on next page)
\end{abstract}


(Continued from previous page)

Keywords: Eco-city, Eco-district, Ecological urbanism, Sustainable development, Environmental sustainability, Renewable resources, Green energy, Smart energy systems, ICT, Data-driven smart solutions

\section{Introduction}

Cities have a defining role in strategic sustainable development. Therefore, they have gained a central position in operationalizing this notion and applying this discourse. This is clearly reflected in the Sustainable Development Goal 11 (SGD 11) of the United Nations' 2030 Agenda, which entails making cities more sustainable, resilient, inclusive, and safe (UN 2015a). In this respect, the UN's 2030 Agenda regards ICT as a means to promote socioeconomic development and protect the environment, increase resource efficiency, achieve human progress and knowledge in societies, upgrade legacy infrastructure, and retrofit industries based on sustainable design principles (UN 2015b). Therefore, the multifaceted potential of the smart city approach as enabled by ICT has been under investigation by the UN (2015c) through their study on 'Big Data and the 2030 Agenda for Sustainable Development.

Sustainable cities have been the leading global paradigm of urbanism (e.g., Bibri 2019a, 2020; Bibri and Krogstie 2017a, b; Jabareen 2006; Van Bueren et al. 2011; Wheeler and Beatley 2010; Whitehead 2003; Williams 2010) for more than three decades. They represent an umbrella term for various models of sustainable urban forms, including eco-cities. In the late 1980s, the discourse on sustainable development produced the notion of the eco-city that became one of the preferred responses to the challenges of sustainable development. Richard Register, an architect widely credited as the first to have coined the term, defined an eco-city in 1987 as 'an urban environmental system in which input (of resources) and output (of waste) are minimized' (Register 2002). This definition highlights that the environmental dimension of sustainability is at the core of the eco-city. However, as the concept has become more established, the meanings associated with it and the diversity of initiatives and projects adopting the label have become widespread across the world. As an umbrella concept, the eco-city encompasses a wide range of urban-ecological proposals that aim to achieve sustainability. These approaches emphasize green energy, smart energy, integrated renewable solutions, passive solar design, green structure, ecological and cultural diversity, and environmentally sound policies (Bibri 2020). Of these strategies, green energy technology remains the most contributor to environmental sustainability in the context of the ecocity. Green energy comes from natural resources, which are renewable. Renewable energy sources include solar, wind, biomass, geothermal, hydropower, and oceanic.

However, in the current climate of the unprecedented urbanization and increased uncertainty of the world, it may be more challenging for eco-cities to reconfigure themselves more sustainably, especially when it comes to energy production and consumption. The predicted $70 \%$ rate of urbanization by 2050 (UN 2015d) reveals that environmental sustainability will be a key factor in global resilience and viability to forthcoming changes. This implies that city governments in the ecologically advanced nations will face significant environmental challenges due to the issues engendered by urban growth. These include increased energy consumption, pollution, toxic waste disposal, resource depletion, inefficient management of resources, and so on, In a nutshell, urban growth raises a variety of problems that tend to 
jeopardize the environmental sustainability of cities, as it puts an enormous strain on energy systems as well as ecosystem services.

Against the backdrop of the unprecedented rate of urbanization and the rising environmental concerns, a number of alternative ways of planning and managing energy resources based on advanced ICT have materialized and are rapidly evolving, enabling eco-cities to improve and advance their contribution to the environmental goals of sustainability (Bibri 2020; Bibri and Krogstie 2020a). Achieving environmental targets in eco-cities has long mostly been based on sustainable energy systems and environmental policies. Advanced ICT constitutes a promising response to the challenges of environmental sustainability in the face of urbanization due to its tremendous, yet untapped, potential for tackling many problems associated with energy management and environmental efficiency (see, e.g., Anthony et al. 2019; Bibri and Krogstie 2020a; Kramers et al. 2014; Shahrokni et al. 2015a, b). Many urban development approaches emphasize the role of big data technologies and their novel applications as an advanced form of ICT in advancing environmental sustainability (e.g., Al Nuaimi et al. 2015; Angelidou et al. 2017; Batty et al. 2012; Bettencourt 2014; Bibri 2018b, 2019b, Bibri and Krogstie 2017b, 2020a, b; Hashem et al. 2016). Indeed, there has recently been a conscious push for sustainable cities across the globe to be smarter and thus more environmentally sustainable by developing and implementing advanced data-driven solutions to enhance and optimize urban operations, functions, services, designs, and strategies (Bibri 2020).

A large body of work has investigated the presumed outcome of the eco-city achieved through planning practices and design strategies. More specifically, scholars have discussed to what extent it produces the expected environmental benefits of sustainability (see, e.g., Bibri and Krogstie 2020a, Holmstedt et al. 2017; Joss et al. 2013; Pandis and Brandt 2011; Rapoport and Vernay 2011; Suzuki et al. 2010)-with a focus on the natural environment and ecosystems (Mostafavi and Doherty 2010). Accordingly, this line of research directs attention to the ecological dimension of sustainability. Moreover, a recent wave of research has started to focus on integrating sustainable cities (especially eco-cities) and smart cities in a variety of ways (e.g., Bibri 2018a, 2019a, 2020; Bibri and Krogstie 2019a, b, 2020a, b; Cowley 2016; Höjer and Wangel 2015; Kramers et al. 2014; Shahrokni et al. 2015a, b; Späth 2017) to improve environmental sustainability.

This paper examines how the eco-city especially its core environmental dimension is practiced and justified in urban planning and development with respect to sustainable energy systems and their integration with data-driven smart technologies at the district level. To provide a theoretical foundation and produce a rationale for this study, this paper provides a state-of-the-art review of the field of ecological urbanism in terms of its foundations, models, strategies, research issues, as well as data-driven smart technological trends.

This paper unfolds as follows. Section 2 describes and justifies the research methodology. Section 3 provides a detailed review on the eco-city. Section 4 presents the results of the case study. Section 5 discusses the results and how they are interpreted in perspective of previous studies, Finally, this paper concludes, in Section 6, by drawing the main findings, providing some reflections, and suggesting some avenues for future research. 


\section{Research methodology}

\section{Descriptive case study design, characteristics, and approach}

Case study research has long been of prominence in many disciplinary and interdisciplinary and fields. Creswell et al. (2007, p. 245) describe case study methodology as 'a type of design in qualitative research, an object of study, and a product of the inquiry.' The authors conclude with a definition that collates the hallmarks of key approaches and that represents the core features of a case study: 'a qualitative approach in which the investigator explores a bounded system (a case) ... over time through detailed, in-depth data collection ... and reports a case description and case-based themes' (Creswell et al. 2007, p. 245).

According to their design, case studies can be divided into several categories, including descriptive, explanatory, exploratory, illustrative, cumulative, and critical instance, each of which is custom selected for use depending on the objectives of the researcher or the purpose in evaluation. Case study research can be used to study a range of topics and for different purposes (Simons 2009; Stake 2006; Stewart 2014; Yin 2017). This case study uses a descriptive design, an approach that is focused and detailed, and in which questions and propositions about the environmental dimension of the eco-city are carefully scrutinized and articulated at the outset. The articulation of what is already known about this phenomenon is called a descriptive theory. Therefore, the main goal of this descriptive case study is to assess the selected case in detail based on such articulation. This research design intends to describe the environmental dimension of the eco-city in its real-world context, to draw on Yin $(2014,2017)$. It is worth pointing out that the internal validity in this design, the approximate truth about inferences regarding cause-effect in relation to this phenomenon, is of irrelevance as in most descriptive studies. It is only relevant in studies that attempt to establish a causal relationship such as explanatory case studies. Indeed, descriptive research is used to describe characteristics of certain phenomena, and does not address questions about how/why/when the characteristics occurred-no causal relationship.

In the context of this paper, descriptive research involves the description, analysis, and interpretation of the present nature, composition, and processes of an eco-city district in Stockholm, Sweden, where the focus is on some prevailing conditions. That is, how this district behaves in terms of what has been realized and the ongoing implementation of plans based on the corresponding environmentally sustainable development strategies associated with sustainable energy systems and energy efficiency processes and their integration. To obtain a broad and detailed knowledge in this regard, we adopted an approach consisting of the following steps:

- Using a narrative framework that focuses on the environmental dimension of the eco-city as a real-world problem and provides essential facts about it, including relevant background information

- Introducing the reader to key concepts, models, strategies, and policies relevant to the problem under investigation.

- Discussing issues, challenges, opportunities, and prospects

- Explaining the actual solutions in terms of plans, the processes of implementing them, and the outcomes

- Offering analysis, evaluation, and discussion of the chosen relevant strategies and solutions and their strengths, weaknesses, and lessons learned. 


\section{Unit of analysis and data collection and analytical methods}

The entity that frames what is to be analyzed is the strategies and solutions of the ecocity for the environment. This is essential to focalizing, framing, and managing data collection and analysis. To identify the perceived link between the relevant eco-city dimensions and the environmental goals of sustainability, the common terms related to the eco-city model were searched for in the two cities' comprehensive plans. The broad concepts represented by these terms linked to the environmental goals of sustainability were then mapped.

In addition, the district's master plans, programs, policy documents, and project descriptions were identified and analyzed using a thematic analysis. This qualitative analytical technique is particularly (albeit not exclusively) associated with the analysis of textual material. Generally, it emphasizes identifying, analyzing, interpreting, and reporting themes, i.e., important patterns of meaning within qualitative data that can be used to address the problem under investigation. Braun and Clarke (2006) suggest that thematic analysis is flexible in terms of theoretical and research design given that it is not dependent on any particular theory or epistemology: multiple theories can be applied to this process across a variety of epistemologies Thematic analysis is an umbrella term for a variety of different approaches, which are divergent in regard to procedures. We adopted an inductive approach to thematic analysis, which allows the data to determine the set of themes that are to be identified. That is to say, we developed our own framework based on what we find as themes (inductive) by discovering patterns, themes, and concepts in the data.

\section{Brief on the case study city and district}

Stockholm is an important global city and one of the world's cleanest capitals and metropolises due to the absence of heavy industry and fossil fuel power plants. Indeed, it has a long history of environmental work and was the first city to be granted the European Union's Green Capital award by the European Commission in 2010 (European Green Capital 2009) because of its high environmental standards and ambitious goals for further environmental improvement. This pertains to climate change, air quality, waste management, wastewater treatment, environmental management, and so on. In particular, the city has a long-term commitment to sustainable development and environmental enhancement.

The City of Stockholm is at the forefront of ecological thinking. It has very strong environmental policies and is focused on improving the quality of life of its citizens (Lindström and Eriksson 1993). It argues that climate-adapted solutions will minimize energy use and waste (Stockholm City 2009b, c), among others. In recent years, much of the environmental work within Stockholm has focused on developing new sustainable urban districts. One recent initiative is the Stockholm Royal Seaport (SRS) district, whose vision is to become a 'world class environmental city district' (City of Stockholm 2010). SRS is an area of 236 ha that is being transformed from a brownfield zone into a site of 12,000 homes, 35,000 workplaces, $600,000 \mathrm{~m} 2$ of commercial spaces, and parks and green spaces, with about 35,000 people to live and/or work in the area.

SRS is designated as an environmental profile area with the mandate to become a model of sustainable urban development (Stockholm City 2019). It is one of the key 
Climate Positive projects in the world that are considered as examples of successful environmental urban developments, demonstrating that cities can reduce carbon emissions and grow in climate friendly ways. The vision of SRS relates to the overall goal established by the City of Stockholm to be fossil fuel-free by 2050 (Stockholm City 2009a). In this respect, SRS environmental profile should consolidate Stockholm's position as a leading capital in climate work, support the marketing of Swedish environmental technology, and contribute to the development of new technology (Stockholm City 2009c).

\section{Literature review}

Ecological urbanism and its relation to green urbanism

Ecological urbanism and green urbanism are common terms that are similar or related to sustainable urbanism. It is argued that ecological urbanism draws from ecology to inspire an urbanism that is more sensitive to the environment and socially inclusive, predicated on the assumption that ecology is concerned with the relationships between all organisms and the environment. Ecological urbanism is also less ideologically driven, i.e., by ideas of a political or economic nature, than green urbanism whose principles are based on the triple-zero framework: zero fossil-fuel energy use, zero waste, and zero emissions. However, both models of urbanism are construed as focusing more on the natural environment and ecosystems and less on economic and social aspects (Mostafavi and Doherty 2010).

Ruano (1998) defines ecological urbanism as 'the development of multi-dimensional sustainable human communities within harmonious and balanced built environments.' Ecological urbanism focuses on developing urban environments based on the principles of ecological sustainability. If ecological urbanism as a holistic approach is to be successful, it needs to design and integrate complex systems and social processes together, and to reflect their synergy in ways that are dynamically interactive or cooperative to produce combined effects greater than the sum of their separate effects with respect to the benefits of sustainability as to its tripartite composition (Bibri 2019a). It is of crucial importance for cities to become masters of a stable, equitable, and ecological urbanism (Brugmann 2009).

Ecological urbanism shares several concepts, ideas, and visions with green urbanism in terms of the role of the city and positive planning and development in shaping better places, communities, and lifestyles. Arguing for the need for new approaches to urbanism to incorporate more ecologically responsible forms of living, Beatley (2000, pp. 6-8) views a city exemplifying green urbanism as one that:

- strives to live within its ecological limits;

- is designed to function in ways analogous to nature;

- strives to achieve a circular rather than a linear metabolism;

- strives toward local and regional self-sufficiency;

- facilitates more sustainable lifestyles; and

- emphasizes a high quality of neighborhood and community life.

A leading example of the models of ecological urbanism is Western Harbour district in Malmö, Sweden. This district is the the first climate-friendly district in Sweden, and 
a great deal of attention in this district has been given to the use of natural resources as well as recycled water, waste, and raw materials. Local energy production is integrated from the start throughout Western Harbor. The Bo01 area currently uses 100\% locally produced energy supply from renewable sources, a concept based on local conditions for energy production (Malmö City 2006). It represents the first step in the process of transforming the 160 hectares of Western Harbor area into a sustainable urban district. When completed, the Western Harbor area will consist of a total of around 11,000 homes and 17,000 jobs, and over 20,000 people will be able to live in the area (Malmö City 2015).

\section{The Eco-city Concept and its definitional issues}

The idea of the eco-city is widely varied in conceptualization and operationalization. In other words, there are multiple definitions of the eco-city, depending on the context where it is embedded in the form of urban projects and initiatives in terms of the practices and strategies adopted to achieve its goals. Broadly, an eco-city is a human settlement which emphasizes the self-sustaining resilient structure and function of natural environment and ecosystems. It seeks to provide a healthy and livable human environment without consuming more renewable resources than it replaces. Roseland (1997a) argues that there is no single accepted definition of the eco-city, but more a collection of ideas about concepts. Joss (2010) corroborates the conceptual diversity and plurality of the initiatives and projects using the term across the globe. The author argues that this makes it difficult to develop a meaningful definition, and ultimately questions the usefulness of attempting to capture a narrow form of definition. Alternatively, he defines the term using three analytical categories: an eco-city must be a development on a substantial scale, occurring across multiple domains, and supported by policy processes (Joss 2011). Jabareen (2006, p. 47) describes the eco-city as an umbrella metaphor which 'encompasses a wide range of urban-ecological proposals that aim to achieve urban sustainability. These approaches propose a wide range of environmental, social, and institutional policies that are directed to managing urban spaces to achieve sustainability.' Joss (2011) succinctly describes it as a collective name for a city scale project that is environmental friendly. A recent study conducted by Rapoport (2014) traces the evolution of the eco-city as a concept and urban planning model over the last 30 years or so, outlining both the various definitions of the term as well as its applications and critiques.

A consistent theme in the literature on eco-cities is that there is no one agreed upon definition of the concept (Joss 2011; Keeton 2011; Roseland 1997a). Worth pointing out is that most of the definitions of the eco-city tend to be associated with the wider socio-cultural context in which this model is embedded in the form of initiatives and projects and related objectives, requirements, resources, and capabilities. This though raises issues related to the analysis of what an eco-city is, which of the underlying design and strategies contributes more to its environmental dimension of sustainability, and the extent to which it considers all the three dimensions of sustainability. Regardless, each city should deal with its own planning and development in the sense of designing the eco-city, adopting its strategies, applying its solutions, and implementing its policies to improve the health of 
the city and the quality of life of its citizens. In addition, city authorities, scientific communities, and industry experts have no common agenda of action when it comes to urban developnent. As concluded by Rapoport and Vernay (2011), who have looked at several eco-city initiatives from across the world, there is no single solution for making urban living more sustainable, so in this sense, it is better to think of the eco-city as an objective that can be achieved in multiple ways.

\section{Design and technology approaches to the eco-city}

There are different models of the eco-city focusing either on passive solar design and greening or green and smart technology. Examples of models that emphasize passive solar design include: the Ecovillage, Solar Village (Van der 1991), Solar City (Joss 2011), Cohousing (Roelofs 1999), and sustainable Housing (Boonstra 2000). Examples of models that combine passive solar design and greening include: Eco-City (Roseland 1997a, b; Engwicht 1992), Ecological City (OECD 1995), Environmental City, Green City, Sustainable City (Girardet 1999; Nijkamp and Perrels 1994; Gibbs et al. 1998), Sustainable Community (Nozick 1992; Paulson 1997), Sustainable Neighborhood (Rudin and Falk 1999), Sustainable Urban Living (Girardet 1992), Living Machines (Todd and Todd 1994), and Garden City (Zhou et al. 2012).

Examples of models that emphasize technology solutions for achieving the environmental objectives of sustainable development include: SymbioCity (Ranhagen and Groth 2012), Carbon Neutral City, Zero Energy City, Zero Carbon City, Eco-Municipality, Eco-Industrial Park (Joss 2011), Low Carbon City (Joss 2011; Zhou et al. 2012), Net Zero Carbon Community (McGregor et al. 2013), Eco2 City (Suzuki et al. 2010), Smart Eco-City (Bibri and Krogstie 2020a, Cowley 2016; Späth 2017), and Ubiquitous Eco-City (Yigitcanlar and Lee 2013).

In view of the above, what exactly constitutes the eco-city as an overarching approach to sustainable urbanism seems to be even unclear and thus difficult to pin down. Today an ever-increasing range of existing districts, cities, as well as new and planned urban initiatives and projects are labelled eco-cities (Rapoport and Vernay 2011). Eco-districts focus on community collaboration, integrated communication, and management to help cities to be more successful by working together. However, the way ecological urban initiatives and projects conceive of the eco-city status reflects more divergences than convergences (Bibri and Krogstie 2017b, 2019b). In other words, the guiding planning documents in this regard tend to be largely developed as independent islands of locally ecological sustainability. Accordingly, it is more appropriate to think of the eco-city as an ambition that can be achieved through multiple ways.

\section{Eco-city strategies and solutions}

The key dimensions of the eco-city, which have been enacted in many cities across the world, include a variety of strategies and solutions for achieving the goals of sustainability (Bibri 2018a, 2019a, 2020; Bibri and Krogstie 2017b, 2020; Farr 2008; Jabareen 2006; Kenworthy 2006, 2019; Lynn et al. 2003), especially in relation to its environmental dimension. Table 1 presents the key strategies and solutions of the eco-city as distilled based on a recent interdisciplinary case study conducted by Bibri (2020): 
Table 1 Key strategies and solutions of the eco-city

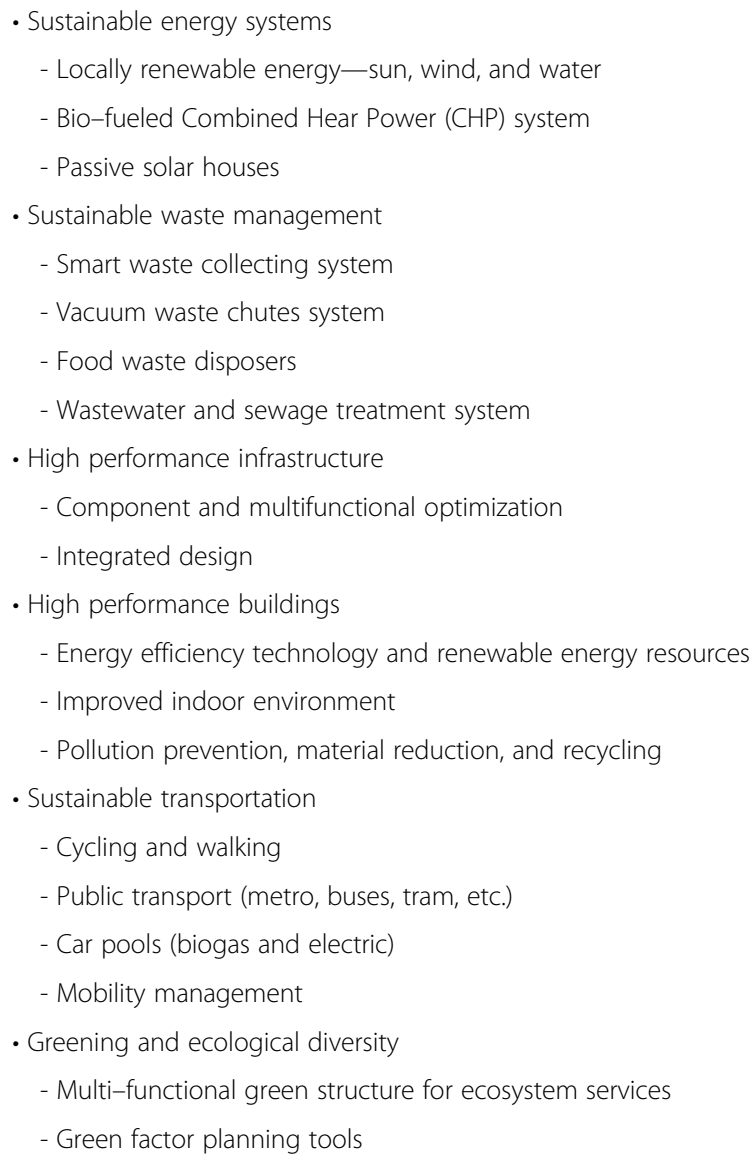

\section{Research issues}

The eco-city has been criticized as an idea that is loosely defined from a set of ostentatiously attractive projects as expensive schemes with aesthetic and commercial ends intended to satisfy a local or regional ambition to invest in ecological sustainability without posing a more theoretically focused and globally applicable approach. Moreover, Cugurullo (2016) questions the sustainability of the so-called eco-city by investigating the extent to which it is developed in a controlled and systematic manner as its developers claim. More specifically, the author counterclaims mainstream understandings of ecological urbanism, arguing that what are promoted as cohesive settlements shaped by a homogeneous vision of the sustainable city, are actually fragmented cities made of disconnected and often incongruous pieces of urban fabric. In reference to eco-cites, Holmstedt et al. (2017) point out that implementing sustainable solutions is more difficult because no unified practical definition is still accepted even if the subject of sustainability has been hotly debated more than three decades, and most projects act dishonesty in order to gain an advantage by not defining what is meant by sustainability and not meeting all requirements. Furthermore, in urban planning and policy making, the concept of the eco-city 'has tended to focus mainly on infrastructures for urban metabolism-sewage, water, energy, and waste management within the city' (Höjer and Wangel 2015, p. 3), thereby falling short in considering smart solutions in relation to 
urban processes and practices (e.g., Bibri 2019a, 2020; Bibri and Krogstie 2017b; Kramers et al. 2014, 2016).

Furthermore, scholars have often critically discussed to what extent the eco-city produces the expected environmental, economic, and social benefits of sustainability. Ideally, for sustainability to be achieved, its environmental, economic, and social dimensions need to be in balance. Whether this is actually the case in the eco-city initiatives or projects varies from one eco-city to another. In conducting a discursive study on six eco-city projects to uncover the diversity underneath the various uses of the term ecocity and to determine the extent of divergence in the way these projects conceive of what an eco-city should be, Rapoport and Vernay (2011) address several categories of discourse, including type of sustainability. Table 2 presents a summary of their analysis of the sets of documents associated with the six projects, and lists the frequency of the statements found accordingly that reflect this category of discourse.

What can be concluded from this tabulated summary is in fact consistent with the literature on ecological urbanism (e.g., Mostafavi and Doherty 2010; Holmstedt et al. 2017; Pandis and Brandt 2011) that the discourse of environmental sustainability clearly dominates over that of economic sustainability and social sustainability (indicated by the relevant numbers highlighted in bold in Table 2). That is, the environmental dimension of sustainability is at the core of the eco-city by its focus on the natural environment and ecosystems. Indeed, the eco-city brings the concern for these two foci to the forefront of urbanism processes and practices.

The contours of a goal hierarchy is evident in eco-city planning and development. Bibri and Krogstie (2020a, b) conclude that the environmental and some economic concerns of sustainability are at the top of the goal hierarchy supporting the eco-city district strategies, notwithstanding the claim about the three dimensions of sustainability being equally important at the discursive level. This is a shortcoming when it comes to sustainability because the social and economic aspects are highly important in the context of sustainable cities. Nonetheless, while the environmental concerns of sustainability remain a key driver of the contemporary eco-city projects, they are also mobilized in the pursuit of politico-economic ends (Bibri 2015). Moreover, the plans and publicity materials of such projects, notably those promoted in Asia and the Middle East as ambitious, technologically-driven projects led by the public and private sector actors contain bold claims, attractive designs, ambitious targets, and innovative technologies to advertise their 'eco-ness' (Rapoport 2014).

\section{Data-driven smart technology solutions: opportunities and prospects}

Generally, a recent research wave has started to focus on advancing sustainable urbanism processes and practices by amalgamating the landscapes of and the approaches to

Table 2 Frequencies

\begin{tabular}{|c|c|c|c|c|c|c|}
\hline & Dongtan & Masdar & Sonama Mountain & Hammarby Sjōstad & Eeo-village Ithaca & Western harbour, B001 \\
\hline \multicolumn{7}{|c|}{ Category 1: type of sustainability } \\
\hline Environmental & 37 & 24 & 28 & 76 & 28 & 64 \\
\hline Social & 8 & 1 & 10 & 12 & 33 & 5 \\
\hline Economic & 12 & 26 & 13 & 8 & 6 & 11 \\
\hline
\end{tabular}

Source: Rapoport and Vernay (2011) 
sustainable cities and smart cities in a variety of ways in the hopes of reaching the optimal level of sustainability, particularly with regard to its environmental dimension. Indeed, it has been argued that ecological urbanism needs to extend its boundaries and broaden its horizons beyond the ambit of green technology and ecological design to include technological innovation opportunities and computational analytics capabilities by unlocking and exploiting the significant potential of big data technology.

Furthermore, smart eco-cities are increasingly becoming more complex with the very technologies being used to deal with their urban infrastructure as to its operational functioning and management. Hence, it is necessary to develop and apply more innovative solutions and sophisticated approaches to monitor, analyze, and plan eco-city systems. Eco-cities can only be smart if there are intelligence functions that are able to integrate and synthesize urban data to improve environmental sustainability through data-driven decisions. Especially, building models of eco-cities functioning in real time from routinely sensed data is becoming a clear prospect, and ubiquitous sensing is getting closer to providing quite useful information about longer term changes (Bibri 2020). These opportunities are part of the ongoing debate on integrating eco-cities and smart cities. This in turn relates to the current issue of sustainable cities and smart cities being extremely fragmented as landscapes and weakly connected as approaches (e.g., Angelidou et al. 2017; Bibri and Krogstie 2019a, b; Kramers et al. 2014), despite the proven role of advanced ICT and the untapped potential of the IoT and big data technologies for advancing environmental sustainability (see Bibri 2019b). Moreover, such technologies are often used in smart cities without making any contribution to environmental sustainability, while the strategies of sustainable cities fall short in considering data-driven smart solutions (Bibri and Krogstie 2017a, b).

It is estimated that 50 billion devices will be connected to the Internet by 2020 (Perera et al. 2014). Already, the number of objects connected to the Internet (e.g., computers, smartphones, WiFi-enabled sensors, wearable devices, household appliances, and many more) has, according to the Cisco report, exceeded the number of human beings in the world (Ahmed et al. 2017). The continuously increasing number of networked devices deployed across urban environments will in turn result in the explosive growth in the amount of the data generated. Consequently, sustainable cities are becoming highly responsive to a form of data-driven urbanism. Besides, we are moving into an era where instrumentation, datafication, and computation are routinely pervading the very fabric of modern cities, coupled with the integration and coordination of their systems and domains. As a result, vast troves of data are generated, analyzed, harnessed, and exploited to control, manage, and regulate urban life.

\section{Results}

\section{Sustainable energy systems}

With its vision to become a world-class environmental city district, SRS has set three ambitious environmental goals, namely (Stockholm City 2019):

- To reduce CO2 emissions from $4.5 \mathrm{t}$ in 2008 to a level below $1.5 \mathrm{t}$ per inhabitant by 2020.

- To be fossil fuel-free and climate + by 2030 .

- To be adapted to a changed climate, i.e., increasing precipitation. 
One of the key strategies of the environmental sustainability program for SRS to achieve the above goals is 'resource efficiency and climate responsibility.' The focus of this strategy is for the City of Stockholm (2020) to develop SRS as a district that strives for a fossil-fuel-free, low-resource, and non-toxic future. Resource flows are designed to be circular, and to minimize environmental and climate impacts. The City of Stockholm argues that for the built environment to be robust over time, it is required that natural resources must be used efficiently and that buildings are designed with high quality (Bibri and Krogstie 2020a).

All new buildings in SRS are being built as low-energy buildings to reduce the energy use. They are provided with a well-insulated building envelope and energy efficient installations, and the roofs are used to generate solar electricity and solar heating, which increases the production of renewable energy (Stockholm City 2020). In this respect, the Municipality of Stockholm set these energy requirements on urban developers: 55 $\mathrm{kWh}$ per $\mathrm{m} 2 \mathrm{x}$ year and $30 \%$ locally produced electricity by renewables. These energy standards are on the focus due to the awareness that greenhouse gases (GHG) emissions in Stockholm mostly come from heating (42\%) and electricity (20\%). The energy requirements are associated with the energy goals set by SRS as shown in Table 3.

Renewable energy generation is strongly advocated in order for SRS to become fossil fuel-free by 2030. Therefore, the future energy system in SRS is planned to be based on renewable sources in order for this district to fulfill the ambition of becoming environmentally sustainable (Stockholm City 2010).

Furthermore, Stockholm has a strong tradition of using district heating as a well-developed, efficient system for the distribution of heating, cooling, and hot water to buildings (Werner 1989). It focuses on low carbon development most notably through widespread district heating and cooling systems (OECD 2013). The environmental sustainability program for SRS states that the energy system must primarily be based on the Bio-fueled CHP system (Stockholm City 2010), which entails local production of electricity by renewables as well as smart waste collecting system. Incineration of household waste is one of the main energy sources for district heating (Fortum 2013). Figure 1 illustrates CHP integrated pyrolysis process in SRS.

Therefore, it is important for SRS to have a waste management system that enables handling waste in an accessible, safe, and environmentally sustainable manner. There are a number of actions in the following areas that are being given priority for the environmental goals for waste management to be achieved in SRS.

Table 3 Energy goals of SRS

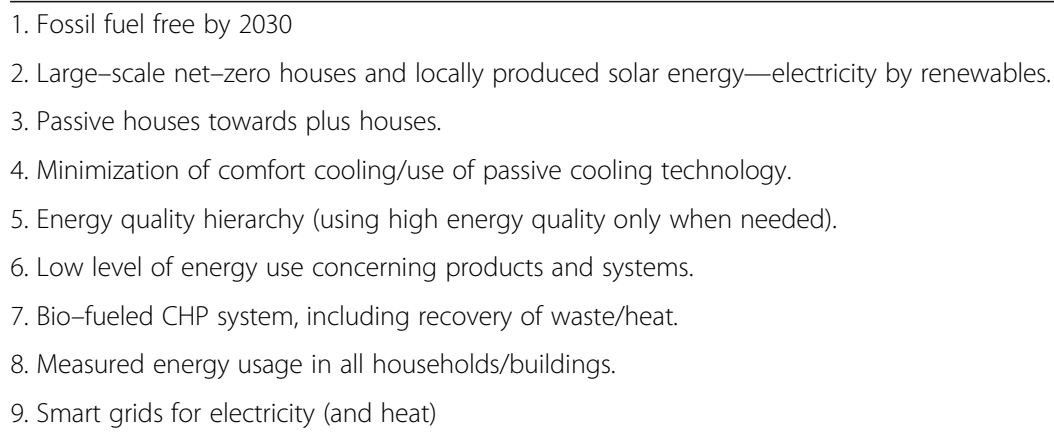




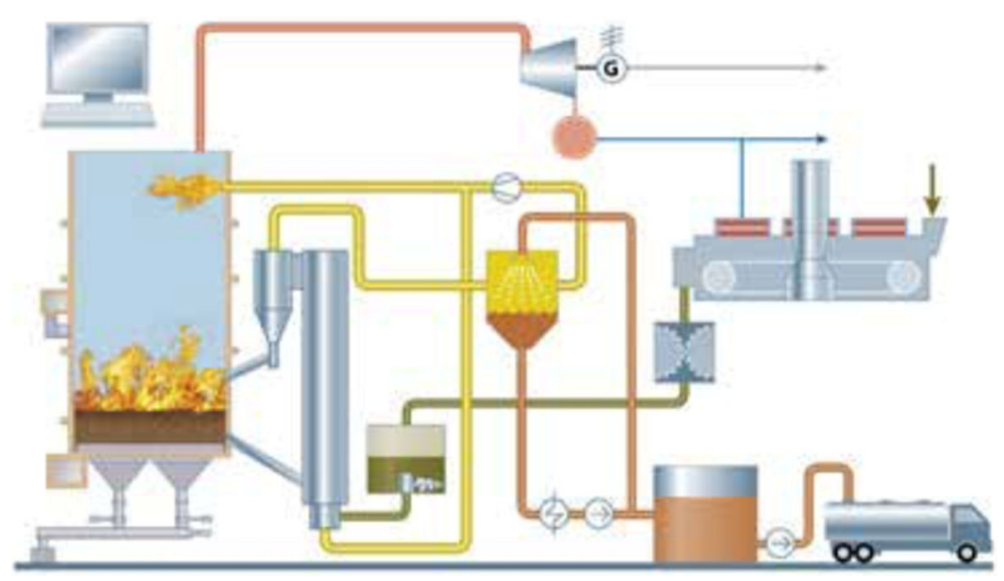

Fig. 1 CHP integrated pyrolysis process in SRS

- Standardize the planning of waste sorting facilities in conjunction with housing and commercial properties.

- Implement the regulations and use the instruments decided on, and monitor progress to ensure they achieve the desired outcomes

- Distribute evenly large waste sorting stations throughout the district, and connect them to the city's waste infrastructure.

- Improve knowledge about pollutants-emissions of hazardous substances from waste-and their long-term risks and effects, and act accordingly.

- Make it easy for households to sort their waste at source in the right way.

- High degree of waste separation in that the household waste fraction should contain food residues and plastics.

- Divide and maintain responsibility between waste producers and authorities, as well as further develop cooperation between them and monitor it together with service levels.

- Handle the integration of wastewater and sewage fractions as important resources in the sustainable energy system.

According to the sustainability report for SRS (Stockholm City 2019), the results achieved in 2017 show that $100 \%$ of the properties are connected to a vacuum waste collection system and $100 \%$ of the kitchens have a waste disposal unit. SRS has high environmental sustainability ambitions, supported by the implementation of advanced technical solutions that can help to fulfill the vision. This must, however, be reinforced by the behavioral change of the local residents through their engagement as part of environmental stewardship. Indeed, the residents are the actual forefront users of new technologies. As stated by Bibri (2020), 'It is up to the residents in SRS to ... adopt sustainable habits and lifestyles. Especially, they have no regulations to adhere to in this regard. Therefore, it is up to the their goodwill and interests and the extent to which they want to live up to the vision of their district.' In this regard, SRS needs to better tap into its potential for building community engagement to better encourage sustainable lifestyles among its residents. 
Regardless, the energy requirements for the buildings in SRS are set high, and will thus decrease the demand for heating in the area (Stockholm City 2010). In this case, it is of importance to develop a flexible system in such a way that it can be adapted for use with other sources of energy as well as integrated with multiple systems. Hence, the utility provider Fortum is currently in the process of building a new bio-fueled CHP plant at its facility in Värtan, which is located in the SRS district (Fortum 2012). This plant will contribute to a further reduction in Stockholm's CO2 emissions by generating $10 \%$ of its electricity needs and $25 \%$ of its district heating needs (Stockholm City 2009c). And since it will distribute district heating to southern and central parts of Stockholm, in addition to SRS, it will contribute to reaching the ambitious emission reduction targets set by the City of Stockholm.

As acknowledged in the environmental sustainability program for SRS, every part of the district that is affected by the energy system, e.g., buildings and infrastructure, must be highly effective, and the goal is that SRS will become a climate-positive district (Stockholm City 2010). According to the sustainability report for SRS (Stockholm City (2019, cited in Bibri and Krogstie 2020a), the results achieved in 2017 show that the energy consumption was reduced by $40 \%$ in total-energy performance lower than national legislation, and actual PVs production is $1 \mathrm{GWh} /$ year. Requirements on energy and waste as smart sustainable solutions implemented by SRS are reducing GHG emissions by about $60 \%$ (The Nordics 2017). However, developing an energy system that is not dependent on fossil fuels involves delicate challenges and developing such system for SRS as a single district can pose even greater ones (Bibri and Krogstie 2020a).

\section{Data-driven smart solutions for energy management and GHG emissions reduction}

Stockholm is the leading Nordic smart sustainable city (Akande et al. 2019). In relevance to this study, the City of Stockholm (2017) sets these targets: to use digitalization and new technologies to make it easier for residents and businesses to be environmentally friendly, and to reduce energy consumption and carbon footprint.

According to the City of Stockholm, an IoT-based infrastructure is highly important for, and the backbone for building, smart sustainable cities nowadays (Bibri and Krogstie 2020a). As Johansson Claes, a project leader, states, 'the reason we are establishing this is because we have a lot of challenges. We know that using the smart technologies can help us to be a better city, for the people that live there, work there and even the people that are visiting us.' He also states that the environmental department in the city is being active with smart technologies. The smart eco-city district of SRS starts with a common vision in smart planning and design on the basis of the IoT technology (The Nordics 2017). Some smart solutions include (Bibri and Krgostie 2020a):

- BigBelly: Waste bins using solar power and packing the trash automatically when needed, notifying when they need emptying.

- Smart lighting: Sensor-controlled Light Emitting Diode (LED) lighting for pedestrian and bicycle paths, self-controlled-LED street lights with preset lighting schedules, and remote-controlled lights.

- Green IT for reducing environmental impacts: energy-efficient buildings (monitoring and optimization), and digital meetings and mobile workings. 
The small-scale tests performed within the different areas of the city to see if smart technologies work have been converted into pilot projects within such domains as smart traffic, smart lighting, air pollution, and the environment (Johannesson 2018). Here the IoT infrastructure is being used to establish and share data from different projects, and the role of private companies should lie in establishing new services out of these data (Bibri and Krogstie 2020a). However, the strategic implementation of ICT was brought in by the environmental program for the City of Stockholm, which involved requirements that SRS should be smart in this direction. Therefore, the environmental targets set by SRS are being supported by the implementation of smart technologies. Among the smart sustainable solutions implemented by SRS are the establishment of digitalized monitoring and feedback processes and triple and quadruple helix R\&D projects (e.g., the IoT, visualization, circular economy (The Nordics 2017). The use of ICT within SRS pertains mainly to the role of technology in reaching environmental targets as part of the digital city plan for the district.

The database systems for collecting the environmental data were secured and being used in SRS to give feedback and inform inhabitants (Bibri 2020). The City administration established a platform that can collect the environmental data given the importance of orchestrating a plethora of various systems. In SRS, ICT solutions are used to visualize and communicate energy use pertaining to households/buildings and smart sustainable system solutions. In this context, a new framework for Smart Urban Metabolism (SUM) has been implemented in SRS as part of a $R \& D$ project (Shahrokni et al. 2015a). In this framework, four key performance indicators (KPIs) are generated in real time based on the integration of heterogeneous, realtime data sources, namely

(1) kilowatt-hours per square meter,

(2) carbon dioxide equivalents per capita

(3) kilowatt-hours of primary energy per capita, and

(4) share of renewables percentage.

These KPIs are fed back on three levels (household, building, and district) on four interfaces, developed for different audiences. The long-term opportunities of SUM include enabling a new understanding of the causalities that govern urbanism and allowing citizens and city officials to receive feedback on the system consequences of their choices. The SUM model works at high temporal (up to real-time) and spatial (down to house-hold/individual) resolutions. In other words, it can, through integrating ICT and smart urban technologies, provide real-time feedback on energy and material flows, from the level of the household to that of the urban district as applied to SRS (Shahrokni et al. 2015b) as shown in Fig. 2.

According to Shahrokni et al. (2015b), the prototype developed for the SRS employs a hybrid approach to the implementation of the SUM concept, with the realtime calculation engine being able to process production and consumption data (see Fig. 3). The current focus of the SRS prototype is to understand the GHG emissions resulting from the consumption of electricity, heat, water, and the production of waste in the SRS. As additionally illustrated in Fig. 3, the implementation of the SUM concept entails three phases: (1) obtaining data, (2) development 
(a) My GHG Emissions Today

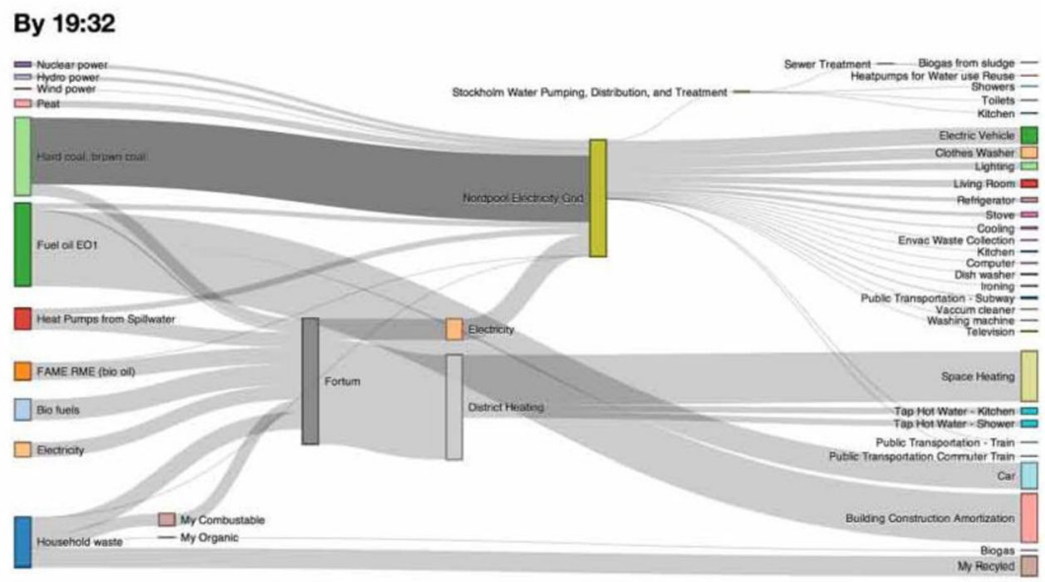

${ }^{(b)}$ My Building's Greenhouse Gas

May 22, 2012 Emissions Today

By 19:32

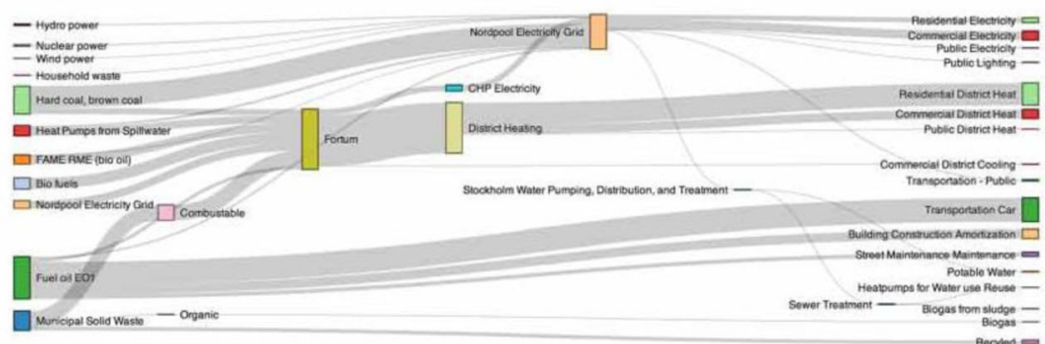

(c) My District's Greenhouse Gas Emissions Today

By 19:32

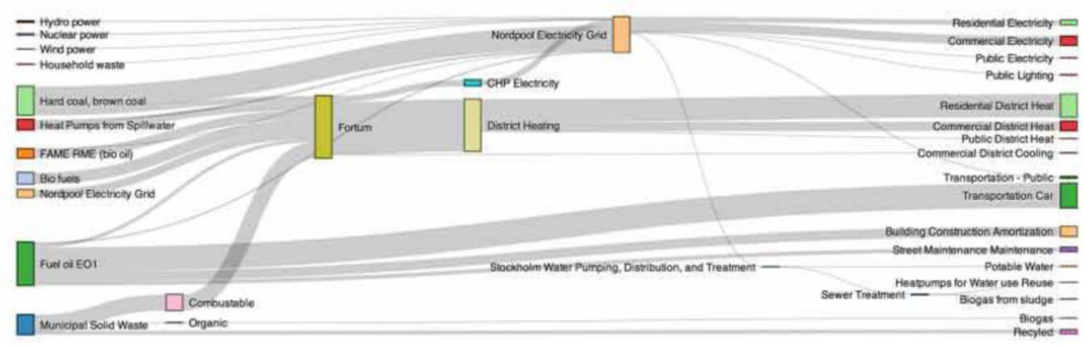

Fig. 2 a Visualization of a household carbon metabolism, b visualization of a building carbon metabolism, and $\mathbf{c}$ visualization of the district's carbon metabolism, all at a given time through the use of Sankey diagrams. Source: Shahrokni et al. (2015b) 


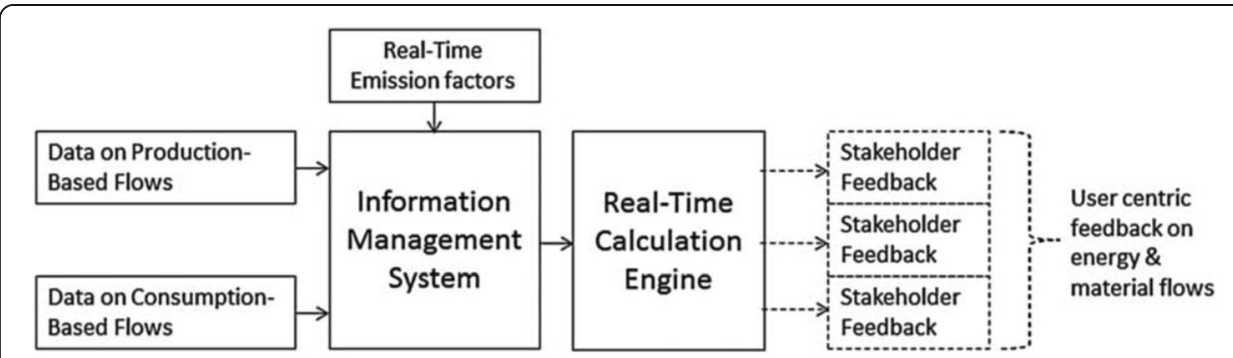

Fig. 3 Data flows for energy and materials in the SRS model. Source: Shahrokni et al. (2015b)

of a calculation engine and data processing, and (3) development of feedback tailored to individual stakeholder requirements.

However, the most challenging barrier identified in relation to SUM is accessing and integrating siloed data from the different data owners, which is hard to overcome unless a significant value is perceived. Also, applying this framework at the city level has been limited by the lack of data at this scale (Shahrokni et al. 2015b). This is actually one of the common challenges pertaining to the implementation of big data analytics and its novel applications in the context of smart sustainable cities (Bibri 2019a; Bibri and Krogstie 2018).

In addition, SRS has implemented a large-scale smart grid system (see Fig. 4). Smart grid is an electrical grid which includes a variety of operation and energy measures, including smart meters, smart appliances, energy efficient resources, as well as renewable energy resources. As such, it is cost-effective, secure, and sustainable. It integrates and coordinates renewable energy production, consumption, and facilities through enabling technologies, energy services, and active users.

Among the data-driven smart applications pertaining to the smart grid system are:

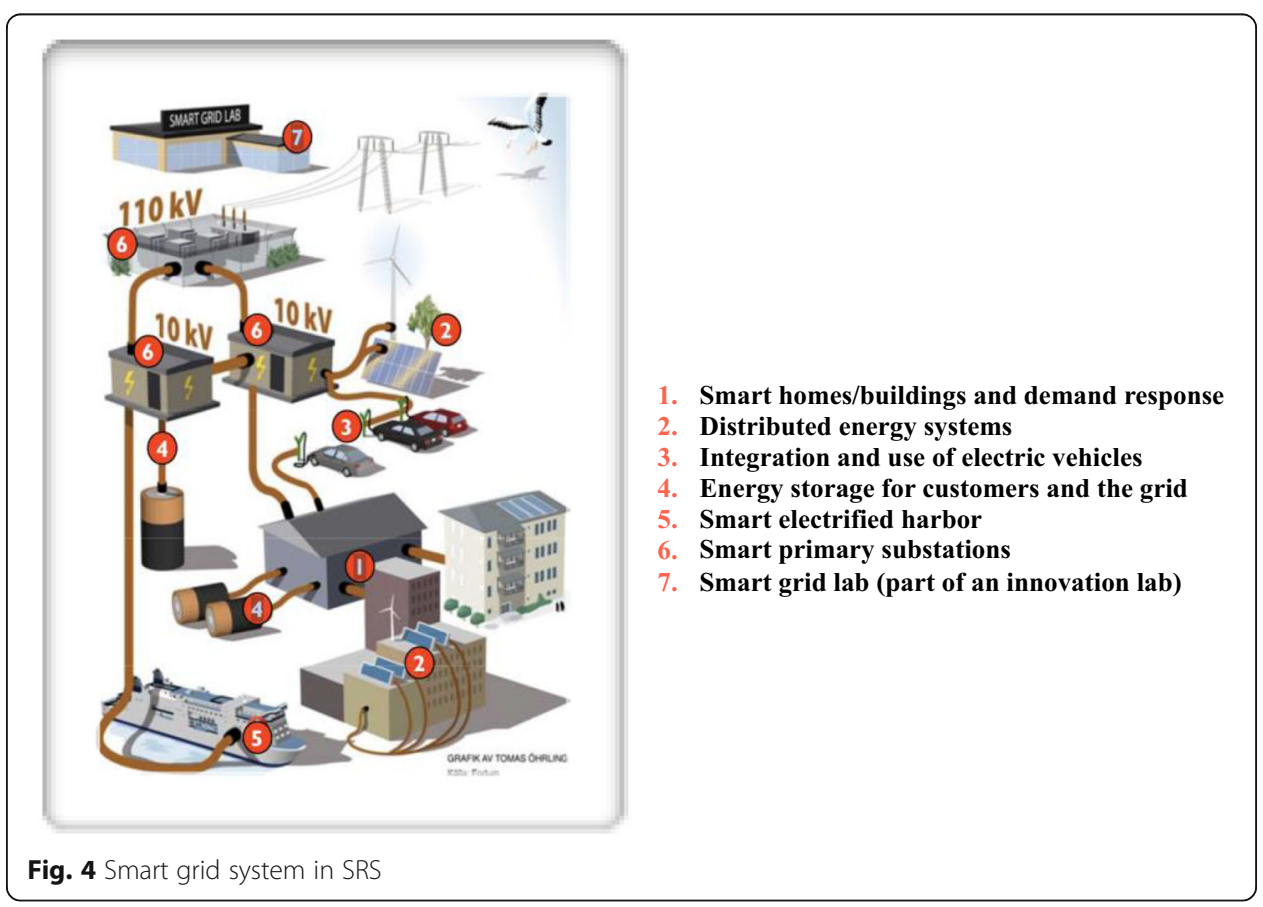




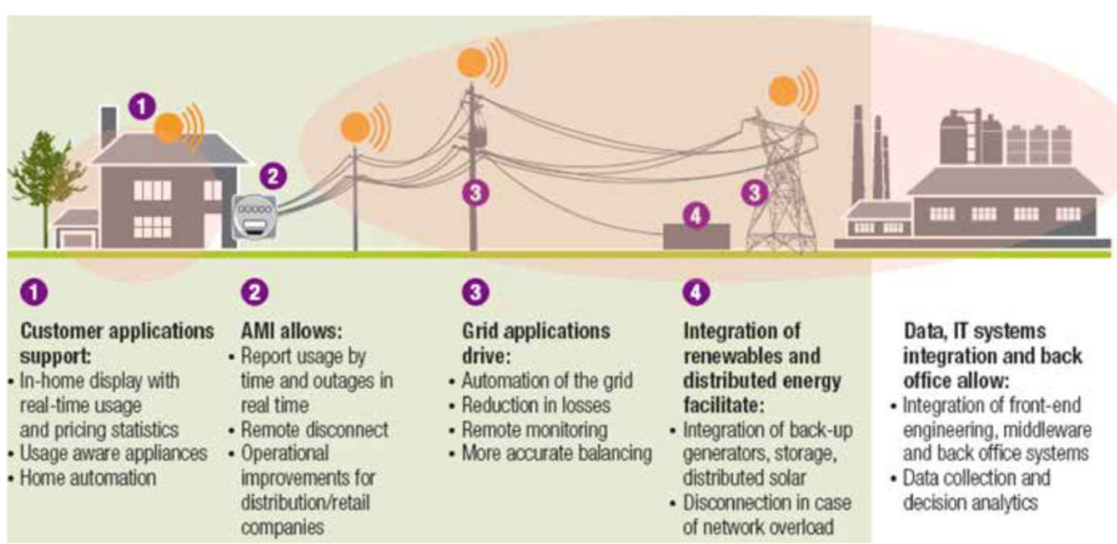

Fig. 5 Smart energy management in SRS

- Supporting decision-making pertaining to the generation and supply of power in line with the actual demand of citizens and other consumers to optimize energy efficiency and thus achieve energy savings.

- Optimizing power distribution networks associated with energy demand and supply.

- Monitoring and analyzing energy consumption and GHG emissions levels in real time across several spatial scales and over different temporal scales, as well as enhancing the performance and effectiveness of the power system.

- Managing distribution automation devices to improve the efficiency, reliability, and sustainability of power production and distribution.

- Avoiding potential power outages resulting from high demand on energy using dynamic pricing models for power usage by increasing charges during peak times to smooth out peaks and applying lower charges during normal times.

- Avoiding the expensive and carbon-intensive peaks in power grid using new ways of coordination with regard to the overall ensemble of users and consumers.

- Enabling power distribution based on a neighborhood model instead of a broadcasting model.

- Improving coordination and planning around power generation from renewable energy plants, as good estimations of power generation from wind, solar panels, and photovoltaic plants can be made in advance.

SRS also uses a number of data-driven smart applications for energy management (see Fig. 5), which allow:

- Citizens to have access to live energy prices and adjust their use accordingly;

- The use of pricing plans in accordance with energy demand and supply models;

- Consumers to manage their usage based on what they actually need and afford;

- Self-optimizing and -controlling energy consumption through integrating sensing and actuation systems in relation to different kinds of appliances and devices for balancing power generation and usage;

- Users to remotely control their home appliances and devices based on the IoT, and providing them with advanced functions like scheduling, programming, and reacting to different contextual situations; 
- Users and consumers to precisely estimate rooftop solar electric potential (PV panels) for almost every building by a simple click or by inputting an address using an interactive online rooftop solar mapping tool; and

- Energy systems to gather and act on near real-time data on power demand, generation, and consumption from end-user connections (information about producers and consumers' behavior).

One of the strengths of the SRS project in terms of the environment that gives it an advantage over other urban development projects lies in cutting-edge green-tech innovations. SRS aims to take the lead in realizing the latest innovations within green and smart technologies. It affords particularly great opportunities for climate-adapted and future-oriented development, from pioneering energy-efficient technical solutions in building and infrastructure to the development of smart electricity networks that enable local production and distribution of electricity (Stockholm City 2009c). The innovation center in SRS will feature the latest developments in environmental technologies and show how related solutions are being tested and applied (Stockholm City 2010). The formal organization in the SRS project works in parallel with the SRS Innovation Arena, which involves industry experts, businesses, and citizens, to build up practical knowledge (Kramers et al. 2016).

However, as with all emerging advanced ICT-enabled solutions, there are several challenges that need to be addressed and overcome in terms of urban planning, design, and development. These challenges in the context of SRS involve the following:

- Sustainable long-term management of the district

- Long-term monitoring of its metabolism

- Silo-thinking within the district administrations

- Transition from pilot to large-scale implementations

In addition, long-term commitment of the Municipality of Stockholm is uncertain when political constellations change (red-green coalition versus blue coalition), despite the promising outcome of the inclusion of advanced ICT in the central governance of the City of Stockholm. Kramers et al. (2016) provide some general lessons learned as to what worked well and what did not in terms of using ICT in the planning phase of SRS as part of city governance.

\section{Discussion}

The findings showed that the Eco-city District of SRS uses green energy technologies and smart data-driven technologies as the key strategies and solutions for achieving the environmental objectives of sustainable development in terms of lowering energy consumption and mitigating pollution. This entails conserving and decreasing the demand for energy through renewable resources-sun, wind, and water, bio-fuelled CHP system, large-scale smart grid system, energy management, sustainable waste management, and passive solar houses. Separated or combined, these outcomes are consistent with the findings of other studies (e.g., Austin 2013; Bibri and Krogstie 2020a; Holmstedt et al. 2017; Pandis and Brandt 2011; Rapoport and Vernay 2011; Register 2006). Several real-world emerging data-driven smart cities strongly support smarter heating, 
electricity, and waste that use resources efficiently and do more with less investments (see Nikitin et al. 2016 for a comprehensive survey). Moreover, sustainable energy systems are being applied as smart solutions in such cities in terms of using renewable resources to support their power grid, such as solar panels distributed throughout the city. For example, Barcelona has required the use of solar water heaters by households since 2006 as well as new large buildings to produce their own domestic hot water since 2000 (Bibri 2020; Bibri and Krogstie 2020b).

The energy sector produces the largest share of the world's emissions of GHG. Therefore, when the energy system is based completely on renewable resources and supported by data-driven smart solutions, coupled with passive and low-energy buildings, sustainable and smart waste management, the reduction of emissions can be very significant. These strategies will make it possible for the SRS district to become climate positive. They will also pave the way for phasing in renewable energy sources and phasing out fossil fuels and potentially support the entire geographical area of the City of Stockholm with renewable energy. In regard to passive solar design, many studies have demonstrated and discussed its environmental benefits (e.g., Gordon 2005; Jabareen 2006; Owens 1992; Thomas 2003; Yeang 1997) related to building heat gains and losses, warming and cooling pressures, heat storage and discharge, emissivity, air and noise pollution reduction, and so forth.

Furthermore, it is important to highlight the role of advanced ICT in SRS in fulfilling its environmental ambition through energy savings by means of the optimization of energy systems and the improvement of energy services. This is consistent with the findings and conclusions from many studies (e.g., Angelidou et al. 2017; Batty et al. 2012; Bibri 2018a, b, 2019a, b, 2020; Höjer and Wangel 2015; Kramers et al. 2014; Townsend 2013). In the context of smart eco-cities, ICT innovation is mostly associated with integrated renewable solutions. These involve the use of analytical, management, modelling, and simulation techniques to enable a wide deployment of renewable energy across districts or cities (Bibri 2018a). Here advanced ICT is embedded in sustainable systems (energy, waste, etc.) in the form of sensor devices and computational processes that monitor, analyze, and plan urban energy to mitigate environmental impacts. In this respect, the IoT and big data are the most applied technologies in developing and implementing efficient processes to enhance and optimize sustainable energy systems. Such technologies use fewer natural resources, optimize energy efficiency, and help reduce pollution or risks to public health and safety. They moreover enable beneficial 'secondary' effects by optimizing energy usage and improving waste management.

The main argument in the ongoing debate over eco-cities is that urban infrastructure (especially power supply system and waste management system) are in themselves complex in terms of operational functioning, management, and planning. Therefore, it has become of crucial importance to develop and apply innovative solutions in this regard for tackling the challenges of environmental sustainability as wicked problems. This requires, among other things, a blend of sciences for creating powerful technology design principles and analytical engineering approaches, with the aim of increasing energy production and decreasing energy consumption. There are numerous applied solutions being implemented in many emerging data-driven smart cities across the globe, which is justified by the high significance of natural resources in urban planning and development strategies. For example, as stated in the Smart London Plan, the City of London (2018) plans to: 
- Promote the use of smart grid technologies to better manage demand and supply of energy.

- Stimulate the use of data and technology to bring efficiencies and scale to the separation and utilization of waste as a resource.

- Investigate longer term infrastructure needs up to 2050-and using data and digital technology to meet those needs.

Worth noting is that London is ranked as one of the leading data-driven smart city in Europe (Bibri 2020, Nikitin et al. 2016). In the early 2010s, it invested heavily in infrastructure, including an extensive IoT sensor network collecting data about energy and environment. Currently, it is using data and technology to build a sustainable citydata-driven sustainable smart city. Hence, there are many lessons for the City of Stockholm to learn from London so that it can improve its technological performance with respect to the application of data-driven smart solutions in the area of environmental sustainability.

In addition, advanced ICT is well placed to do a lot as to enhancing and optimizing energy systems and processes because its application to complex systems is founded on the integration of computer science, data science, urban science, complexity science (Batty et al. 2012; Bibri 2020; Bettencourt 2014; Kitchin 2014, 2016), data-intensive science, and sustainability science (Bibri 2019d, e). The ultimate aim is to find more effective approaches based on the IoT and big data technologies to improve, advance, and maintain the contribution of the eco-city to the goals of environmental sustainability. However, the rising demand for such technologies, coupled with the growing recognition of their potential to transform the way sustainable cities can be planned and designed and thus operate and function, comes with major challenges pertaining to the design, engineering, development, implementation, and maintenance of data-driven smart applications. These challenges are mostly computational, analytical, and technical in nature, and sometimes logistic in terms of the detailed organization and deployment of complex technical operations, adding to the financial, organizational, institutional, regulatory, and ethical ones as pertaining to the application, retention, and dissemination of big data (Bibri 2019c). Regardless, as pointed out by Cowley (2016), the smart ecological ideals have succeeded in enabling action around the world, and have recently become normalized as widely accepted consensus concepts and ideas. The author concludes by recognizing that the utopian rhetoric mobilized in the promotion of the smart-eco city may provide sensible grounds for useful critical evaluations, but also proposes some ways in which it might be understood as a positive attribute. In general, as argued by Rapoport (2014), while the ability of eco-cities to achieve their utopian ambitions may be limited by the realities of being of a profit-driven, entrepreneurial nature, they can still help drive broader sociotechnical transitions, and also play a valuable role in regard to providing a place to test innovative ideas and an ideal to aspire to. Besides, Bibri (2019f) concludes that data-driven smart sustainable urbanism is shaped by socio-cultural and politico-institutional structures, and will prevail for many years yet to come given the underlying transformational power of big data science and analytics, coupled with its legitimation capacity associated with the scientific discourse as the 
ultimate form of rational thought and the basis for legitimacy in knowledge-making and policy-making.

\section{Conclusions}

The eco-city has long been one of the key preferred responses to the challenges of environmentally sustainable development, especially through its energy and climate strategies. The Eco-district of SRS is seen as exemplary practical initiative in environmental sustainability at national, supranational, and international scales. This study has been carried out as a demonstration endeavor of what SRS is renowned for in regard to its environmental profile.

The aim of this study was to examine how the eco-city especially its core environmental dimension is practiced and justified in urban planning and development with respect to sustainable energy systems and their integration with data-driven smart technologies at the district level. This study shows that the Eco-city District of SRS uses green energy and smart data-driven technologies as the key strategies and solutions for achieving the environmental objectives of sustainable development in terms of lowering energy consumption and mitigating pollution. This entails conserving and decreasing the demand for energy through renewable resources (sun, wind, and water), bio-fuelled CHP system, large-scale smart grid system, energy management, sustainable waste management, and passive solar houses. Production focused solutions incorporate green technologies to generate renewable energy, and consumption focused solutions use smart technologies and passive solar design to optimize and slash energy demand.

There is much enthusiasm currently about the opportunities created by the data deluge and its new and more extensive sources in the domain of ecological urbanism, particularly in relation to energy systems given their key role in mitigating the negative impacts on the environment. The availability of data from energy production and consumption is offering the opportunity for continuously providing an integrated view of the environmental effects of the way energy systems are functioning in real time. The real-time data collection and analytics on the energy flows can be used to follow up on the environmental goals of sustainability by optimizing energy use as related to utilities and building owners, as well as by mitigating the environmental impacts of energy consumption as related to households thanks to user-generated automated data collection, real-time analytics, and tailored feedback. The prospect of the real-time data collection and analysis at any instant will provide the opportunity for aggregating such data to deal with urban changes at any scale and over any time period. Datasets show the realtime functioning of energy systems and provide deep insights into how long term changes can be detected and hence dealt with. Short-termism in energy planning is about measuring, evaluating, modelling, and simulating what takes place over hours, days, or weeks instead of months or years. In this respect, big data can be used to derive new theories of how energy systems function in ways that focus on much shorter term issues than hitherto. Continuous energy planning as data constantly flood from energy systems and are updated in real time allows for a dynamic conception of such planning in response to processual outcomes of urbanization as regards building and living processes and consumption and production levels.

We hope that the case study has produced the kind of results which will be useful in directing further research by providing the grounding for more in-depth investigation 
on the eco-city at the district level, especially in relation to energy planning and management. We would particularly like to encourage qualitative research of the kind that we have attempted, which try to illuminate the environmental dimension of the ecocity and the assumptions behind related energy initiatives. And hence the claims that this model can make urban living more environmentally sustainable. The rationale for this is that as the demand for practical ideas, especially those related to integrated renewable solutions, from the ecologically advanced nations about how to achieve the requirements of environmental sustainability through ecological urbanism increases, those initiatives are likely to attract attention from strategic urban actors around the world. Further research should focus on providing the knowledge that these actors will need to make informed decisions about how to achieve the environmental objectives of the eco-city in their own context with regard to the integration of green and datadriven smart energy technologies. Lastly, we believe that the insights gained form this study can help advance the understanding of how the eco-city phenomenon is evolving and adapting to emerging technologies associated with sustainable energy systems.

\section{Abbreviations}

CHP: Combined Heat Power; GHG: Greenhouse Gases; ICT: Information and Communication Technology; loT: Internet of Things; KPI: Key Performance Indicators; LED: Light Emitting Diode; SRS: Stockholm Royal Seaport; SUM: Smart Urban Metabolism

\section{Acknowledgements}

Not applicable.

Author contribution

The author read and approved the final manuscript.

Funding

This research has received no funding.

Availability of data and materials

Not applicable.

\section{Competing interests}

The author declares no competing interests.

Received: 10 March 2020 Accepted: 30 April 2020

Published online: 15 June 2020

\section{References}

Ahmed E, Yaqoob I, Hashem IAT, Khan I, Ahmed AIA, Imran M, Vasilakos AV (2017) The role of big data analytics in internet of things. J Comp Net 129:459-471

Akande A, Gomes P, Cabral P (2019) The Lisbon Ranking for Smart Sustainable Cities in Europe. Sustain Cities Soc 44:475-487. Al Nuaimi E, Al Neyadi H, Nader M, Al-Jaroodi J (2015) Applications of big data to smart cities. J Internet Serv Appl 6(25):1-15 Angelidou M, Artemis P, Nicos K, Christina K, Tsarchopoulos P, Anastasia P (2017) Enhancing sustainable urban development through smart city applications. J Sci Technol Policy Manag:1-25

Anthony B, Petersen SA, Ahlers D et al (2019) Big data-oriented energy prosumption service in smart community districts: a multi-case study perspective. Energy Inform 2:36. https://doi.org/10.1186/s42162-019-0101-3

Austin G (2013) Case study and sustainability assessment of Bo01, Malmo, Sweden. J Green Build Summer 8:34-50

Batty M, Axhausen KW, Giannotti F, Pozdnoukhov A, Bazzani A, Wachowicz M, Ouzounis G, Portugali Y (2012) Smart cities of the future. Eur Phys J 214:481-518

Beatley T (2000) Green urbanism: learning from European cities. Island Press, Washington, DC

Bettencourt LMA (2014) The uses of big data in cities. Santa Fe Institute, Santa Fe

Bibri SE (2015) The shaping of ambient intelligence and the internet of things: historico-epistemic, socio-cultural, politicoinstitutional and eco-environmental dimensions. Springer, Berlin

Bibri SE (2018a) Smart sustainable cities of the future: the untapped potential of big data analytics and context aware computing for advancing sustainability. Springer, Germany

Bibri SE (2018b) The loT for smart sustainable cities of the future: an analytical framework for sensor-based big data applications for environmental sustainability. Sustain Cities Soc 38:230-253

Bibri SE (2019a) Big data science and analytics for smart sustainable urbanism: unprecedented paradigmatic shifts and practical advancements. Springer, Germany

Bibri SE (2019b) The anatomy of the data-driven smart sustainable city: instrumentation, datafication, computerization and related applications. J Big Data 6:59 
Bibri SE (2019c) On the sustainability of smart and smarter cities in the era of big data: an interdisciplinary and transdisciplinary literature review. J Big Data 6(25):2-64

Bibri SE (2019d) The sciences underlying smart sustainable urbanism: unprecedented paradigmatic and scholarly shifts in light of big data science and analytics. Smart Cities 2(2):179-213

Bibri SE (2019e) Advances in smart sustainable urbanism: data-driven and data-intensive scientific approaches to wicked problems, proceedings of the 4th annual international conference on smart city applications, ACM, Oct 2-4, Casablanca, Morocco

Bibri SE (2019f) Data-driven smart sustainable urbanism: the intertwined societal factors underlying its materialization, success, expansion, and evolution. GeoJournal. https://doi.org/10.1007/s10708-019-10061-x

Bibri SE (2020) Advances in the leading paradigms of urbanism and their amalgamation: compact cities, eco-cities, and data-driven smart cities. Springer, Berlin

Bibri SE, Krogstie J (2017a) Smart sustainable cities of the future: an extensive interdisciplinary literature review. Sustain Cities Soc 31:183-212

Bibri SE, Krogstie J (2017b) ICT of the new wave of computing for sustainable urban forms: their big data and context-aware augmented typologies and design concepts. Sustain Cities Soc 32:449-474

Bibri SE, Krogstie J (2018) The big data deluge for transforming the knowledge of smart sustainable cities: a data mining framework for urban analytics, Proceedings of the $3 \mathrm{~d}$ annual international conference on smart city applications, ACM, Oct 11-12, Tetouan, Morocco

Bibri SE, Krogstie J (2019a) A scholarly backcasting approach to a novel model for smart sustainable city of the future: strategic problem orientation. City Territ Archit 6:3

Bibri SE, Krogstie J (2019b) Generating a vision for smart sustainable city of the future: a scholarly backcasting approach. Eur J Futures Res 7:5

Bibri SE, Krogstie J (2020a) Smart eco-city strategies and solutions for sustainability: the cases of Royal Seaport, Stockholm, and Western Harbor, Malmö, Sweden. Urban Sci 11(6):1-42

Bibri SE, Krogstie J (2020b) The Emerging data-driven smart city and its innovative applied solutions for sustainability: the cases of London and Barcelona. J Urban Sci in press

Boonstra C (2000) Sustainable housing: the Dutch experi- ence. In: Edwards B, Turrent D (eds) Sustainable housing: principles and practice. E \& FN Spon, Loon, pp 66-71

Braun V, Clarke V (2006) Using thematic analysis in psychology. Qual Res Psychol 3:77-101.

Brugmann J (2009) Welcome to the urban revolution: how cities are changing the world. Bloomsbury Press, London

Cowley R (2016) Science fiction and the smart eco-city, The Society for the History of Technology Annual Meeting 2016, Singapore, 22-26

Creswell JW, Hanson WE, Clark Plano VL, Morales A (2007) Qualitative research designs: Selection and implementation. Couns Psychol 35:236-264.

Cugurullo F (2016) Exposing smart cities and eco-cities: Frankenstein urbanism and the sustainability challenges of the experimental city. Environ Plan A: Econ Space 50(1):73-92

Engwicht D (1992) Towards an eco-city: calming the traffic. Envirobook, Sydney

European Green Capital (2009) The expert panel's evaluation work final recom-mendations for the European Green Capital Award of 2010 and 2011

Farr D (2008) Sustainable urbanism. Wiley, Hoboken

Fortum (2013) Fortum Värme och miljö Stockholm 2013. Fortum, Stockholm

Fortum (2012) Fortum to Invest in a New Biofuelled Combined Heat and Power Plant in Stockholm. Sweden. Available online: http://www.fortum.com/en/mediaroom/Pages/fortum-to-invest-in-a-newbiofuelled-combined-heat-and-powerplant-in-stockholm-sweden.aspx.

Gibbs DC, Longhurst J, Braithwaite C (1998) Struggling with sustainability: weak and strong interpretations of sustainable development within local authority policy. Environ Plan A 30:1351-1365

Girardet H (1992) The Gaia atlas of cities: new directions for sustainable urban living. Gaia Books, London

Girardet H (1999) Creating sustainable cities. Schumacher briefing no. 2. Green Books, Foxhole

Gordon H (2005) Sustainable design goes main stream. In: Brown D, Fox M, Pelletier MR (eds) Sustainable architecture: white papers. Earthpledge, New York, pp 34-38

Hashem IAT, Chang V, Anuar NB, Adewole, K, Yaqoob I, Gani A, Ahmed E, Chiroma H (2016) The role of big data in smart city. Int J Infor Manag 36:748-758.

Höjer M, Wangel S (2015) Smart sustainable cities: definition and challenges. In: Hilty L, Aebischer BB (eds) ICT innovations for sustainability. Springer, Berlin, pp 333-349

Holmstedt L, Brandt N, Robert KH (2017) Can Stockholm Royal Seaport be part of the puzzle towards global sustainability? From local to global sustainability using the same set of criteria. J Clean Prod 140(2017):72-80

Jabareen YR (2006) Sustainable urban forms: their typologies, models, and concepts. J Plan Educ Res 26:38-52

Johannesson C (2018) City of S.: Interview Claes Johannesson, smart city Stockholm, project leader

Joss S (2010) Eco-cities-a global survey 2009. WIT Trans Ecol Environ 129:239-250

Joss S (2011) Eco-cities: the mainstreaming of urban sustainability; key characteristics and driving factors. Int J Sustain Dev Plan 6(3):268-285

Joss S, Cowley R, Tomozeiu D (2013) Towards the ubiquitous eco-city: an analysis of the internationalisation of eco-city policy and practice. J Urban Res Pract 76:16-22

Keeton R (2011) Rising in the east-contemporary new towns in Asia. SUN Architecture, Amsterdam

Kenworthy JR (2006) The eco-city: ten key transport and planning dimensions for sustainable city development. Environ Urban 18(1):67-85

Kenworthy JR (2019) Urban transport and eco-urbanism: a global comparative study of cities with a special focus on five larger Swedish urban regions, Urban Science, MDPI

Kitchin R (2014) The real-time city? Big data and smart urbanism. Geochem J 79:1-14

Kitchin R (2016) The ethics of smart cities and urban science. Phil Trans R Soc A 374:1-15

Kramers A, Höjer M, Lövehagen N, Wangel J (2014) Smart sustainable cities: Exploring ICT solutions for reduced energy use in cities. Environ Model Softw 56:52-62. 
Kramers A, Wangel J, Höjer M (2016) Governing the smart sustainable city: the case of the Stockholm Royal Seaport. In: Proceedings of ICT for sustainability 2016, vol 46. Atlantis Press, Amsterdam, pp 99-108

Lindström B, Eriksson B (1993) Quality of life among children in the Nordic countries. Qual Life Res 2(1):23-32 London City (2018) https://www.london.gov.uk/sites/default/files/smart_london_plan.pd.

Lynn R, Anderson G, Santore MK (2003) US Environmental Protection Agency, pp 340-368 Retrieved 20 Nov 2011

Malmö City (2006) Västra Hamnen The Bo01-area: a city for people and the environment, https://malmo.se/download/18.71 01 b483110ca54a562800010420/

Malmö City Council (2015) Western Harbor, current urban planning. https://malmo.se/download/18.76b7688614bb5ccea0915 7af/1491304414891/Current+urban+development+in+Western+Harbour+\%282015\%29.pdf

McGregor A, Roberts C, Cousins F (2013) Two degrees: the built environment and our changing climate. Routledge, New York Mostafavi M, Doherty G (2010) Ecological urbanism. Lars Muller, Baden

Nijkamp P, Perrels A (1994) Sustainable cities in Europe. Earthscan, London

Nikitin K, Lantsev N, Nugaev A, Yakovleva A (2016) Data-driven cities: from concept to applied solutions. PricewaterhouseCoopers (PwC), London http://docplayer.net/50140321-From-concept-to-applied-solutions-data-driven-cities.html

Nozick M (1992) No place like the home: building sustainable com- munities. Canadian Council on Social Development, Ottawa

OECD. (1995) Ecological cities project. http://www.oecd.org

OECD (2013) Green growth in Stockholm, Sweden. In: OECD green growth studies. OECD Publishing, Stockholm. https://doi. org/10.1787/9789264195158-en Accessed 21 Apr 2014

Owens S (1992) Energy, environmental sustainability and land-use planning. In: Breheny M (ed) Sustainable development and urban form. Pion, London, pp 79-105

Pandis IS, Brandt N (2011) The development of a sustainable urban district in Hammarby Sjöstad, Stockholm, Sweden? Environ Dev Sustain 13(6):1043-1064

Paulson B (1997) Toward global sustainable community: a view from Wisconsin. In Sustainable global community in the information age: Vision from future studies, ed. Kaoru Yamaguchi. Praeger Studies on the 21st Century. Praeger, Westport.

Perera C, Zaslavsky A, Christen P, Georgakopoulos D (2014) Sensing as a service model for smart cities supported by internet of things, transactions on emerging telecommunication technologies, pp 1-12

Ranhagen U, Groth K (2012) The Symbio City approach - a conceptual framework for sustainable urban development Rapoport E (2014) Utopian visions and real estate dreams: the eco-city past, present and future. Geogr Compass 8:137-149

Rapoport E, Vernay AL (2011) Defining the eco-city: a discursive approach. Paper presented at the management and innovation for a sustainable built environment conference, international eco-cities initiative (pp. 1-15). Amsterdam: the Netherlands

Register R (2002) Eco-cities: building cities in balance with nature. Berkeley Hills Books, Berkeley

Register R (2006) Ecocities: Building Cities in Balance with Nature. New Society Publishers, Gabriola Island.

Roelofs J (1999) Building and designing with nature: urban design. In: David S (ed) Sustainable cities. Earthscan, London, pp 234-250

Roseland M (1997a) Dimensions of the eco-city. Cities 14(4):197-202

Roseland M (1997b) Eco-city dimensions: healthy communities, healthy planet. New Society Publisher, Gabriola Island

Ruano M (1998) Eco-urbanism: sustainable human settlements, 60 case studies - Gustavo Gili

Rudin D, Falk N (1999) Building the 21st century home: the sustainable urban neighborhood. Architectural Press, Oxford

Shahrokni H, Årman L, Lazarevic D, Nilsson A, Brandt N (2015a) Implementing smart urban metabolism in the Stockholm Royal Seaport: smart city SRS. J Ind Ecol 19(5):917-929

Shahrokni H, Lazarevic D, Brandt N (2015b) Smart urban metabolism: towards a real-time understanding of the energy and material flows of a city and its citizens. J Urban Technol 22(1):65-86

Simons H (2009) Case Study Research in Practice. Sage, Los Angeles.

Späth P (2017) Smart - eco cities in Germany: trends and city profiles. University of Exeter (SMART - ECO Project), Exeter Stake RE (2006) Multiple Case Study Analysis. Guilford, New York.

Stewart A (2014) Case study. In Qualitative Methodology: A Practical Guide. Jane M, Melanie B, Eds.; Sage, Thousand Oaks, pp. $145-159$.

Stockholm City (2009a) Stockholm City plan. https://www.google.com/search?client=safari\&channel=mac_bm\&sxsrf= ACYBGNRBW8_dDG-xq9KckAdoe504Heffxg\%3A1572425899931\&source=hp\&ei=q1C5XaeRNY3RrgTI57aYCg\&q= Stockholm+Master+plan+\&btnK=Google+Search

Stockholm City (2009b) Stockholm City Plan, https://vaxer.stockholm/globalassets/tema/oversiktplan-ny_light/english_ stockholm_city_plan.pdf

Stockholm City (2009c) Stockholm Royal Seaport: vision 2030, https://international.stockholm.se/globalassets/ovriga-bilderoch-filer/visionsrs2030_medium.pdf

Stockholm City (2019) Royal Seaport Stockholm. http://www.stockholmroyalseaport.com

Stockholm City Council (2010) Övergripande program för miljö och hållbar stadsutveckling i Norra Djurgårdsstaden. Stockholm City Council, Stockholm

Stockholm City (2017) Smart and Connected City Stockholm. http://international.stockholm.se/globalassets/ovriga-bilder-ochfiler/smart-city/brochuresmart-and-connected.pdf.

Stockholm City (2020) Royal Seaport Stockholm. http://www.stockholmroyalseaport.com.

Suzuki $\mathrm{H}$ et al (2010) Eco2 cities ecological cities as economic cities. The World Bank, Washington, DC

The Nordics (2017) Smart City Solutions, http://www.nordicpavilion.org/stockholm-royal-seaport-2018/

Thomas R (2003) Building design. In: Randall T, Fordham M (eds) Sustainable urban design: an environmental approach. Spon Press, London, pp 46-88

Todd J, Todd N (1994) From eco-cities to living machines: principles of ecological design. North Atlantic Books, Berkeley

Townsend A (2013) Smart cities - big data, civic hackers and the quest for a new utopia. Norton \& Company, New York

United Nations (2015a) Transforming our world: the 2030 agenda for sustainable development. United Nations, New York Available at: https://sustainabledevelopment.un.org/post2015/transformingourworld

United Nations (2015b) Habitat III issue papers, 21-Smart cities (V2.0). United Nations, New York Available at: https:// collaboration.worldbank.org/docs/DOC-20778. Accessed 2 May 2017

United Nations (2015c) Big data and the 2030 agenda for sustainable development. Prepared by A. Maaroof. Available at: www. unescap.org/events/call-participants-big-data-and-2030-agendasustainable-development-achieving-development 
United Nations (2015d) World urbanization prospects. The 2014 revision. New York: Department of Economic and Social Affairs. http://esa.un.org/unpd/wup/Publications/Files/WUP2014-Report.pdf. Accessed 22 Jan 2017.

Van Bueren E, van Bohemen H, Itard L, Visscher H (2011) Sustainable urban environments: an ecosystem approach. Springer, International Publishing

Van der Ryn S, Calthorpe P (1991) Sustainable communities: a new design synthesis for cities, suburbs, and towns. Sierra Club Books, San Francisco

Werner S (1989) Fjärrvärmens utveckling och utbredning. Värmeverksföreningen, Stockholm

Wheeler SM, Beatley T (eds) (2010) The sustainable urban development reader. Routledge, London, New York

Whitehead M (2003) (Re)analysing the sustainable city: nature, urbanism and the regulation of socio-environmental relations in the UK. Urban Stud 40(7):1183-1206

Williams K (2010) Sustainable cities: research and practice challenges. Int J Urban Sustain Dev 1(1):128-132

Yeang K (1997) The skyscraper bioclimatically considered. Academy, London

Yigitcanlar T, Lee SH (2013) Korean ubiquitous-eco-city: a smart-sustainable urban form or a branding hoax? J Tech For Soc Ch 89:100-114

Yin RK (2017) Case study research and applications. In: Design and methods, 6th edn. SAGE Publications, Inc, London

Yin RK (2014) Case study research: design and methods. Sage, Los Angeles

Zhou, N. He, G. \& Williams, C. (2012) China's development of low-carbon eco-cities and associated indicator systems. Report LBNL-5873E, China Energy Group Energy Analysis \& Environmental Impacts Department, Ernest Orlando Lawrence Berkley National Laboratory, p. 1, July 2012, Available at: http://china.lbl.gov/sites/all/fles/china_eco-cities_indicator_ systems.pdf

\section{Publisher's Note}

Springer Nature remains neutral with regard to jurisdictional claims in published maps and institutional affiliations.

\section{Submit your manuscript to a SpringerOpen ${ }^{\circ}$} journal and benefit from:

- Convenient online submission

- Rigorous peer review

Open access: articles freely available online

High visibility within the field

Retaining the copyright to your article

Submit your next manuscript at $>$ springeropen.com 